Keywords:

Chemical control

Drift

Paricá

Weeds

Histórico:

Recebido 24/02/2017

Aceito 05/06/2017

Palavras chave:

Controle químico

Deriva

Paricá

Plantas daninhas

+Correspondência: kaleoef@gmail.com
Kaléo Dias Pereira ${ }^{1+}$, Rafael Gomes Viana², Jonilson Ribeiro Trindade², Rafael Amaral Cardoso²

\section{MORPHOLOGICAL AND PHYSIOLOGICAL CHANGES ON Schizolobium parahyba VAR. Amazonicum (HUBER EX DUCKE) BARNEBY PLANTS INTOXICATED BY GLYPHOSATE}

ABSTRACT: The objective of this study was to evaluate the morphological and physiological changes in paricá plants (Schizolobium parahyba var. amazonicum) intoxicated by glyphosate. The experiment was conducted in a protected environment using paricá plants during their planting stage, which were intoxicated with increasing doses of glyphosate: 0 (control); 43.2; 86.2; 129.6 and I72.8 g.ha- ${ }^{-1}$. At 7 and 21 days after the application of the herbicide, the photosynthesis, transpiration, stomatal conductance and leaf temperature were measured. The visual intoxication degree and the growth of the shoot and the root of the plants were evaluated 21 days after the application. Paricá shows symptoms of visual intoxication characterized by chlorosis/winding, evolving to necrosis/abscission of the youngest leaflets. The growth of the stem and the roots of the intoxicated plants is preserved; however, an expressive leaf loss occurs, and paricá may have adaptation mechanisms to tolerate the action of the herbicide molecule. The photosynthesis decrease promoted by an indirect action of glyphosate represents the main reduction on the growth of plants. The decrease on the stomatal conductance, which was the most sensitive physiological variable to glyphosate, resulted in lower transpiration rates, which, consequently, caused increases on the leaf temperature.

\section{MODIFICAÇÕES MORFOLÓGICAS E FISIOLÓGICAS EM PLANTAS DE Schizolobium parahyba VAR. amazonicum (HUBER EX DUCKE) BARNEBY INTOXICADAS POR GLYPHOSATE}

RESUMO: Objetivou-se avaliar as variações morfofisiológicas em plantas de paricá (Schizolobium parahyba var. amazonicum) intoxicadas por glyphosate. O experimento foi realizado em ambiente protegido utilizando plantas de paricá em idade de plantio, as quais foram intoxicadas com doses crescentes de glyphosate: 0 (testemunha); 43,2; 86,2; 129,6 e 172,8 $\mathrm{g} \cdot \mathrm{ha}^{-1}$. Aos 7 e 21 dias após a aplicação do herbicida, foram realizadas medições da fotossíntese líquida, transpiração, condutância estomática e temperatura da folha. O grau de intoxicação visual e crescimento da parte aérea e da raiz das plantas foram avaliados aos 21 dias após a aplicação. O paricá manifesta sintomas de intoxicação visual caracterizados por clorose/enrolamento e evolução para necrose/abscisão dos foliolulos mais novos. O crescimento do caule e da raiz das plantas intoxicadas é conservado, contudo, há expressiva perda foliar, podendo o paricá possuir mecanismos de adaptação para tolerar a ação da molécula do herbicida. O decréscimo promovido na fotossíntese por ação indireta do glyphosate representa a principal causa da redução no crescimento das plantas. $O$ decréscimo na condutância estomática, a qual demonstrou ser a variável fisiológica mais sensível ao glyphosate, resultou em menores taxas de transpiração, que, consequentemente, ocasionou elevações na temperatura da folha. 


\section{INTRODUCTION}

In 2012, the Brazilian government presented the final version of the Low Carbon Agricultural Plan - ABC Plan, which, among other goals, established the commitment of expanding the planted forest areas to 9 million hectares until 2020 (MAPA/MDA, 201 I). According to IBGE (20I4), in 20I4, the area with forest plantations had exceeded 9.3 million hectares, mostly occupied by eucalyptus and pine plantations. Among the native species of the Amazon, Schizolobium parahyba var. amazonicum (Huber ex Ducke) Barneby (LEWIS, 2016), locally known as paricá, is currently one of the main species used for reforestation purposes, with over 89 thousand planted hectares (IBÁ, 20I5).

The growing interest for paricá is due to its quick growth. It may reach a productivity of $38 \mathrm{~m}^{3} \cdot \mathrm{ha}^{-1} \cdot$ year $^{-1}$ (CARVALHO, 2007) even with no improvement degree; therefore, it is one of the few native species that may catch up with the productivity of eucalyptus. Another determining factor, according to Marques et al. (2006), is the increase on the demand for wood to produce laminates and plywood, a context in which paricá is inserted (ROSA, 2006a).

Although some silvicultural aspects related to the culture of paricá have already been relatively widely studied, there are still gaps of information, such as in relation to the management of weeds. Rosa (2006b) mentions the procedure used by the company Pampa, Vigia - PA, as an example of weed management in paricá plantations in the Amazon, which uses mechanical hoeing and chemical control of weeds with glyphosate. According to the monitoring data of the company, the elimination of weeds resulted in a reduction from 25 to $6 \%$ of paricá mortality during the first year in the field.

Therefore, weed control is necessary with the purpose of minimizing the potential interferences on the culture of paricá that may, somehow, reduce the productivity of the species. The use of herbicides is an attractive option, since it reduces costs and increases the operational yield (SILVA et al., 2007a).

It is important to point out that there are no herbicides to be used on paricá plantations registered at the Ministry of Agriculture, Livestock and Supply, nor there are studies that evaluate the effects of herbicides on the species. It is necessary to determine the levels and types of damages that may be caused to paricá in case of herbicide intoxication, or even whether selectivity to the applied product occurs.

Studies conducted with eucalyptus under the effect of glyphosate drift found significant reductions on the plant development and physiological changes (TUFFI SANTOS et al., 2007b; MACHADO et al., 20I0). In practice, according to Tuffi Santos et al. (2007a), the damages caused by the glyphosate drift, or by some other herbicide, distributed at different levels on the plantation, would increase the heterogeneity of the plot, since the intraspecific competition is favorable to the less affected individuals. The commercial plantations of paricá are still constituted by seminal plantings, therefore, the drift effect would be added to the genetic variability of the plants, making the heterogeneity of the population more accentuated.

Considering the implications of the drift on the development of the forest plantation, our objective was to evaluate the morphological and physiological changes on young paricá plants (Schizolobium parahyba var. amazonicum) intoxicated by glyphosate.

\section{MATERIAL AND METHODS}

The study was conducted in a protected environment with $50 \%$ shading and lateral openings for air circulation. The three-month old paricá plantings were planted on pots with capacity for $7 \mathrm{~L}$, containing a substrate constituted by soil and nutshells at a 2:I proportion ( $v / v)$. After planting, the seedlings went through an acclimatization period of 20 days, during which two fertilizations were conducted with $10 \mathrm{~g}$ of NPK per pot at a 10-28-20 formulation (CARVALHO, 2005; LOPES et al., 20I5).

At the end of the acclimatization period, a drift simulation was conducted, applying five treatments related to reduced doses of glyphosate: 0 (control); 43.2; 86.2; 129.6 and $172.8 \mathrm{~g} \cdot \mathrm{ha}^{-1}$ of active ingredient on acid equivalent, according to the sub-doses used by Machado et al. (2010) on a study with eucalyptus. The herbicide was applied by a $\mathrm{CO}_{2}$ pressurized sprayer, constituted by a Im-wide bar equipped with two TTI 1002 spraying nozzles, previously calibrated for a spray volume of 200 $L \cdot h a^{-1}$. The sprayed solution was directly applied on the plant leaves.

On the day of the application, the plants were distributed so that the treatments had equal height means, which was equivalent to a general mean of 4 I.34 $\mathrm{cm}$. The experiment was established on random blocks, with five replications, and an experimental unit was constituted by one pot with one plant.

The physiological evaluations were conducted 7 and $2 \mathrm{I}$ days after the application of glyphosate, between 9a.m. and I2p.m., every day, using an infrared gas analyzer (model LI-6400XT from LI-COR). The physiological 
parameters analyzed were photosynthesis $(A)$, stomatal conductance $\left(g_{s}\right)$, transpiration $(E)$ and leaf temperature $\left(T_{f}\right)$, at constant light $\left(I 500 \mu \mathrm{mol} \cdot \mathrm{m}^{-2} \cdot \mathrm{s}^{-1}\right)$ and $\mathrm{CO}_{2}(400$ $\mu \mathrm{mol})$ levels. For the readings, were selected leaves located on the intermediate region of the plants.

At 2 I days after the application, the visual toxicity degree was verified according to grade scales from 0 to $100 \%$ of intoxication (FRANS, 1972), the stem base diameter and height were measured, and the root, stem and leaves of all plants were collected. After collecting the material, the leaf area was measured using a leaf area analyzer (model LAI 3I00C). Finally, all of the collected material was subjected to the drying process on a forceair-circulation oven at $50^{\circ} \mathrm{C}$ for 72 hours, posteriorly weighting the dry mass of the root, stem and leaves.

The morphology and physiology data were subjected to the normality analysis by the KolmogorovSmirnov test at $5 \%$ of significance, homogeneity analysis through the Levene test at 5\%, and homogenization of the treatments based on the standard deviation. A regression analysis was conducted with the use of models that showed an adequate adjustment. The comparisons with the control plants were conducted through the Dunnett test at $I$ and $5 \%$ of significance.

\section{RESULTS AND DISCUSSION}

The visual toxicity symptoms on paricá were clearly manifested on plants that received $172.8 \mathrm{~g} \cdot \mathrm{ha}^{-1}$ of glyphosate. They were initially characterized by chlorosis and winding of the leaflets before evolving to necrosis and leaf abscission. The symptoms started to manifest between the fifth and the seventh day after application, always from the youngest leaflets to the oldest ones, from the top of the leaf blade toward the basis.

Since glyphosate is a molecule that is translocated through the phloem, a higher concentration of it and an effect on parts of the plant with greater carbohydrate discharge is common, such as on growth points and strong drains (HETHERINGTON et al., I999; MONQUERO et al., 2004). Although no records of the effect of glyphosate on paricá were found, the symptoms observed on this study are similar to the ones observed on eucalyptus by Tuffi Santos et al. (2009), with the difference that the symptoms on paricá were more evident for the dose of $172.8 \mathrm{~g} \cdot \mathrm{ha}^{-1}$ of glyphosate.

The visual intoxication observed 21 days after the application of glyphosate reached its maximum degree at a dose of I $72.8 \mathrm{~g} \cdot \mathrm{ha}^{-1}$ of a.i. on acid equivalent, causing $43 \%$ of leaf damages (Figure IA). From the dose of $86.2 \mathrm{~g} \cdot \mathrm{ha}^{-1}$, significant damages occurred in relation to the control plant (Table I). Although paricá has shown relatively reasonable resistance when intoxication symptoms are considered, it was observed that a reduction occurred on the leaf area from the dose of $43.2 \mathrm{~g} \cdot \mathrm{ha}^{-1}$ of glyphosate in relation to the control. The mean leaf area of the plants sprayed with $172.8 \mathrm{~g} \cdot \mathrm{ha}^{-1}$ was $507.57 \mathrm{~cm}^{2}$ (Table I), which is equivalent to approximately $20 \%$ of the mean on the control (Figure IB).

Evaluating the effect of glyphosate on different eucalyptus clones, Machado et al. (20I0) verified, 21 days after the application, that the $172.8 \mathrm{~g} \cdot \mathrm{ha}^{-1}$ dose of a.i. on acid equivalent caused from 70 to $86 \%$ of leaf damages. The same dose was tested on five eucalyptus species by Tuffi Santos et al. (2006), and a mean of $47.5 \%$ of intoxication 15 days after the application was observed; only Eucalyptus resinifera and $E$. grandis showed damages below $50 \%$.

TABLE I Morphologicalvariables ofS. parahybavar. amazonicum 2I days after the application of glyphosate.

\begin{tabular}{cccccc}
\hline \multirow{2}{*}{ Variables } & \multicolumn{5}{c}{ Glyphosate dose $\left(\mathrm{g} \cdot \mathrm{ha}^{-1}\right.$ on acid equivalent) } \\
\cline { 2 - 6 } $\begin{array}{c}\text { Visual } \\
\text { intoxication }\end{array}$ & 0 & 43,2 & 86,2 & 129,6 & 172,8 \\
\hline Leaf area & $2,527.82$ & $1,725.27^{*}$ & $806.64^{*} *$ & $548.32^{* *}$ & $507.57^{*} *$ \\
Stem Diameter & 9.25 & $9.14 \mathrm{~ns}$ & $8.73 \mathrm{~ns}$ & $7.57^{*}$ & $8.22 \mathrm{~ns}$ \\
Height & 57.08 & $51.90 \mathrm{~ns}$ & $52.08 \mathrm{~ns}$ & $46.28^{*} *$ & $48.58^{*}$ \\
Leaf dry mass & 10.82 & $8.32 \mathrm{~ns}$ & $3.94 * *$ & $2.63^{* *}$ & $2.33^{* * *}$ \\
Stem dry mass & 9.35 & $8.23 \mathrm{~ns}$ & $6.89 \mathrm{~ns}$ & $5.5 I^{*}$ & $6.39 \mathrm{~ns}$ \\
Root dry mass & 2.24 & $2.48 \mathrm{~ns}$ & $1.65 \mathrm{~ns}$ & $1.42 \mathrm{~ns}$ & $1.57 \mathrm{~ns}$ \\
Total dry mass & 22.42 & $19.03 \mathrm{~ns}$ & $12.48^{*} *$ & $9.56^{* *}$ & $10.29 * *$ \\
\hline
\end{tabular}

'Comparison with dose 0 (control) on the row: ns - non-significant; * and ** significant difference according to the Dunnett test at 5 and $1 \%$, respectively.

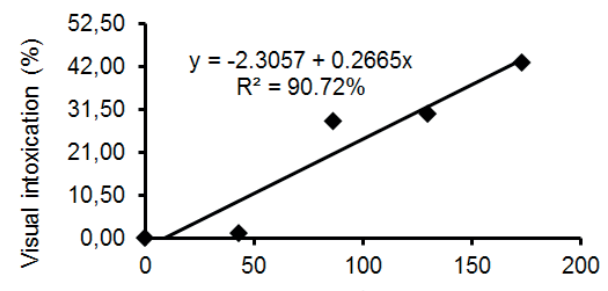

A Glyphosate dose ( $\mathrm{g} \cdot \mathrm{ha}^{-1}$ on acid equivalent)

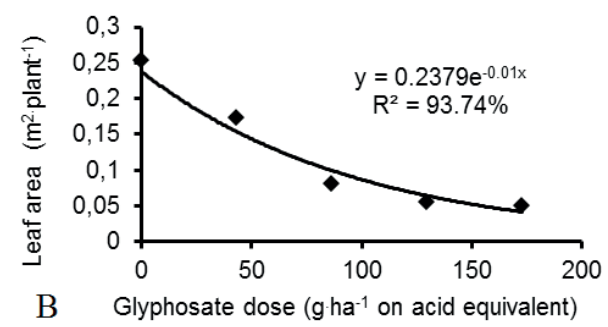

FIGURE I Visual intoxication degree and leaf area of $S$. parahyba var. amazonicum 21 days after the application of glyphosate. 
On a study conducted by Wagner Júnior et al. (2008) with passion fruit (Passiflora edulis), the intoxication was below $10 \%$ up to 28 days after the application of $172.8 \mathrm{~g} \cdot \mathrm{ha}^{-1}$ of glyphosate, similarly to what Yamashita et al. (2006) observed on Parkia multijuga plants. The drift effect on Jatropha curcas evaluated on the study by Costa et al. (2009) reached $38.7 \%$ of intoxication 21 days after the application of $180 \mathrm{~g} \cdot \mathrm{ha}^{-1}$.

Costa et al. (2012) observed a more mild leaf loss tendency on Eucalyptus grandis, reaching a reduction of $57.6 \%$ with $120 \mathrm{~g} \cdot \mathrm{ha}^{-1}$ of glyphosate applied only on the leaves. Magalhães et al. (200 la) and Magalhães et al. (200 lb) did not observe a significant variation on the leaf area of maize and sorghum, respectively, using doses of up to $172.8 \mathrm{~g} \cdot \mathrm{ha}^{-1}$ of glyphosate.

The leaf abscission observed must have occurred probably due to the increase on the ethylene production through an indirect action of glyphosate (FUCHS et al., 2002; GRAVENA, 2006). According to Yamada and Castro (2007), ethylene increases the cellulase activity, which makes the leaves more susceptible to abscission, in addition to promoting the loss of chlorophyll; therefore, it is one of the factors responsible for the chlorosis. Ethylene derives from the amino acid methionine (SCHALLER; KIEBER, 2002), which is, in turn, produced at a greater amount when the molecule of the herbicide inhibits the route that originates the aromatic amino acids phenylalanine, tryptophan and tyrosine (YAMADA; CASTRO, 2007).

The height of the plants varied significantly from the dose of $129.6 \mathrm{~g} \cdot \mathrm{ha}^{-1}$ (Table I), and a reduction occurred on approximately $15 \%$ with the dose of 172.8 $\mathrm{g} \mathrm{ha}^{-1}$ in relation to the control (Figure 2A). There was a smaller variation on the diameter, and a decrease slightly above $11 \%$ occurred at the highest dose in comparison to the control (Figure 2B).

Using clones of hybrids of Eucalyptus grandis $\mathrm{x}$ E. urophylla, Santos Junior et al. (2005) evaluated the total height and diameter (measured at $1.3 \mathrm{~m}$ ) 30 days after the application of $1,080 \mathrm{~g} \cdot \mathrm{ha}^{-1}$ of glyphosate on $100 \%$ of the basal branches and observed reductions of 33.19 and $31.44 \%$, respectively. Costa et al. (2012) verified a reduction of $37.5 \%$ on the stem diameter 28 days after the application of $120 \mathrm{~g} \cdot \mathrm{ha}^{-1}$ of glyphosate. Tuffi Santos et al. (2006) did not observe variations on the height and diameter of $E$. urophylla 45 days after the application of up to $172.8 \mathrm{~g} \cdot \mathrm{ha}^{-1}$ of glyphosate, although it has also been compared together with other molecules and combinations.
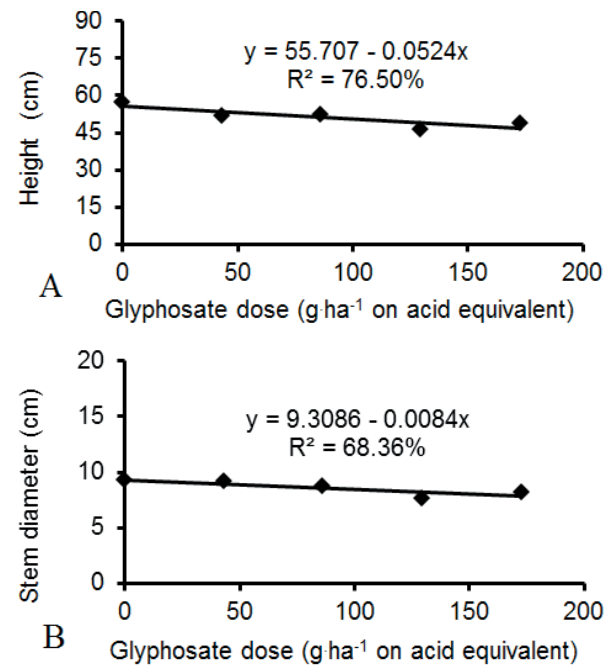

FIGURE 2 Height and stem diameter of $S$. parahyba var. amazonicum 2 I days after the application of glyphosate.

The total dry mass was reduced in approximately $55 \%$ with the application of $172.8 \mathrm{~g} \cdot \mathrm{ha}^{-1}$ (Figure $3 \mathrm{~A}$ ), observing a significant variation from the $86.2 \mathrm{~g} \cdot \mathrm{ha}^{-1}$ dose in relation to the control mean (Table I). Both the stem dry mass and the root dry mass suffered a reduction of approximately $30 \%$ on the most intoxicated plants when compared to the control plants. Although the decrease on the total dry mass was expressive, this is mostly due to the loss of leaf dry mass (Figure $3 \mathrm{~A}$ and $\mathrm{B}$ ), with a reduction of almost $80 \%$ upon the application of the highest dose. Only the mean of the lowest dose was equal to the control (Table I).

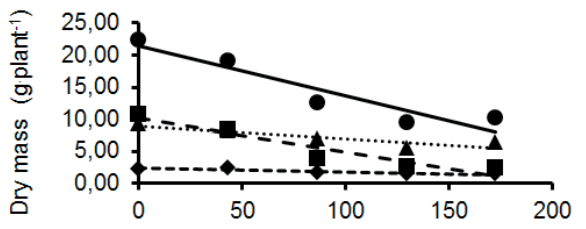

A Glyphosate dose ( $\mathrm{g} \mathrm{ha} \mathrm{a}^{-1}$ on acid equivalent)

- Root $y=2.3512-0.0056 x ; R^{2}=67.84 \%$

- Leafy $=10.141-0.0525 x ; R^{2}=90.25 \%$

$\Delta$ Stem $y=9.004-0.02 x ; R^{2}=80.58 \%$

- Total $y=21.496-0.0781 x ; R^{2}=88.06 \%$

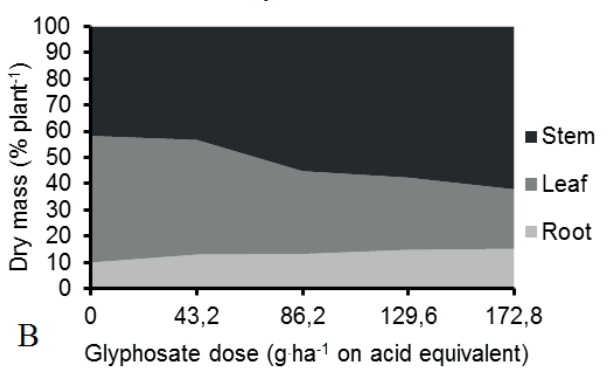

FIGURE 3 Dry mass of the root, leaf, stem, total dry mass (A) and participation of assimilates on the total dry mass (B) of S. parahyba var. amazonicum 2I days after the application of glyphosate. 
In order to reduce the dry mass of the root, leaves and stem of paricá in $50 \%$, doses of $219.86 ; 90.10$ and

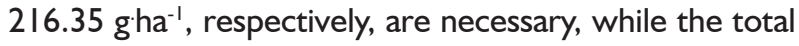
dry mass is reduced with $131.73 \mathrm{~g} \mathrm{ha}^{-1}$.

In opposition to the reduction on the leaf area and the leaf dry mass, the growth of the diameter and the root was relatively not much affect; this could be the effect of some self-preservation mechanism, such as the change on the translocation of carbohydrates in order to limit the action of the herbicide molecule (SILVA et al., 2007b).

According to Salgado et al. (20I I), the dry mass of the leaves and stem of hybrids of Eucalyptus grandis $x E$. urophylla is reduced in half with the application of 143.3 to $277.4 \mathrm{~g}^{\mathrm{ha}} \mathrm{h}^{-1}$ of glyphosate. In the case of the study conducted by Silva et al. (2015), the mass of the shoot components of Eucalyptus "urograndis" was reduced in

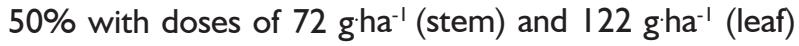
of glyphosate, while, for Pinus taeda, the same effect was promoted by doses of $120 \mathrm{~g} \cdot \mathrm{ha}^{-1}$ (stem) and $44 \mathrm{~g} \cdot \mathrm{ha}^{-1}$ (leaf) of glyphosate.

The growth inhibition due to the action of glyphosate, both on the shoot and on the root, occurs partially due to the reduction on the synthesis and the concentration of indoleacetic acid (IAA) (LEE; DUMAS, 1983; LEE; DUMAS, 1985), as well as due to the reduction on the translocation speed of the hormone (BAUR, 1979). Yamada and Castro (2007) explain that, by inhibiting the synthesis of phenolic compounds, glyphosate reduces the concentration of the IAA precursor (tryptophan) and increases the IAA-oxidase activity, which would be normally regulated by the phenolic compounds. With the increase on the activity of the IAA-oxidase enzyme, the metabolism of free IAA increases, especially on plants that are sensitive to the herbicide, as observed by Lee and Dumas (1985).

The effect of glyphosate on $A$ for paricá led to a more accentuated reduction 2 I days after the application (Figure 4A), and there was a significant difference in relation to the control from the $129.6 \mathrm{~g}^{\mathrm{h}} \mathrm{ha}^{-1}$ dose (Table 2 ). Considering the data collected 21 days after the application, the dose of $124.7 \mathrm{~g} \cdot \mathrm{ha}^{-1}$ of active ingredient on acid equivalent of glyphosate is enough to cause a $50 \%$ reduction of $A$ for paricá.

On a study with Eucalyptus, Machado et al. (2010) only observed a change on $A 2$ I days after the intoxication by glyphosate. Carvalho et al. (2013) observed a decrease on the photosynthesis rate of coffee 15 days after the application of $60.8 \mathrm{gha}^{-1}$ of glyphosate.

The reduction of $A$ is related, among other factors, to an important secondary effect of glyphosate, which consists in deviating erythrose-4-phosphate, which would be used for the regeneration of ribulose bisphosphate on the Calvin cycle, for the deregulated route of shikimate, thus, reducing the carbon fixation capacity of the plant (YAMADA; CASTRO, 2007). Such phenomenon was shown by Servaites et al. (1987) on a study with common beat (Beta vulgaris), in which they observed a $50 \%$ reduction on the ribulose bisphosphate activity 12 hours after the application of $17 \mathrm{mmol}^{\text {plant }}{ }^{-1}$.

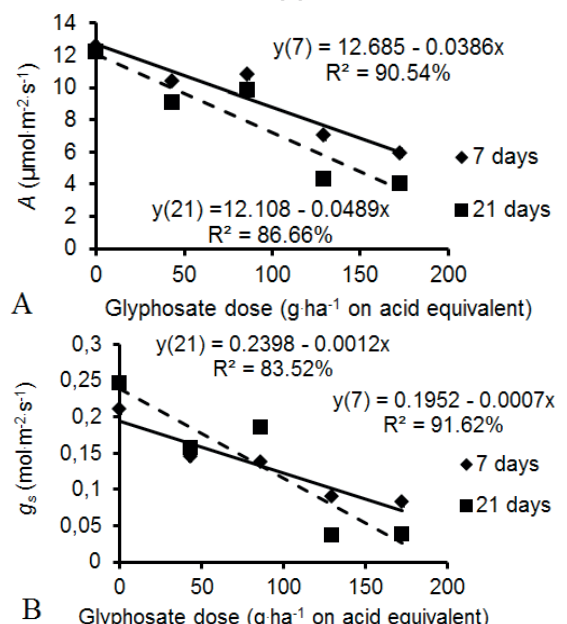

B Glyphosate dose ( $\mathrm{g} \mathrm{ha}^{-1}$ on acid equivalent)

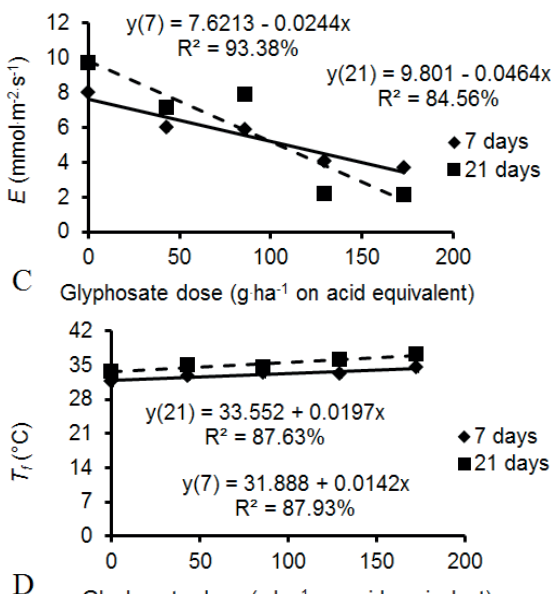

D Glyphosate dose ( $\mathrm{g} \cdot \mathrm{ha}^{-1}$ on acid equivalent)

Air temperature: $32.39^{\circ} \mathrm{C}(7$ days $)$ and $33.87^{\circ} \mathrm{C}$ ( 2 I days).

FIGURE 4 Photosynthesis (A), stomatal conductance (gs), transpiration (E) and leaf temperature (Tf) of S. parahyba var. amazonicum 7 and 21 days after the application of glyphosate.

TABLE 2 Physiological variables of S. parahyba var. amazonicum 7 and 21 days after the application of glyphosate.

\begin{tabular}{|c|c|c|c|c|c|}
\hline \multirow{2}{*}{ Variables } & \multicolumn{5}{|c|}{ Glyphosate dose ( $\mathrm{g} \cdot \mathrm{ha}^{-1}$ on acid equivalent) } \\
\hline & 0 & 43,2 & 86,2 & 129,6 & 172,8 \\
\hline \multicolumn{6}{|c|}{7 days after the application } \\
\hline Photosynthesis & $12.59^{1}$ & I0.40ns & $10.80 \mathrm{~ns}$ & $7.03 \mathrm{~ns}$ & $5.94 *$ \\
\hline Stomatal conductance & 0.21 & $0.15 n s$ & $0.14 \mathrm{~ns}$ & $0.09 *$ & $0.08 *$ \\
\hline Transpiration & 7.97 & $6.0 \mathrm{Ins}$ & $5.85 \mathrm{~ns}$ & 4.04* & $3.68^{*}$ \\
\hline Leaf temperature & 31.63 & $32.87 n s$ & $33.32 \mathrm{~ns}$ & $33.24 \mathrm{~ns}$ & $34.52 *$ \\
\hline \multicolumn{6}{|c|}{21 days after the application } \\
\hline Photosynthesis & 12.200 & $9.07 \mathrm{Ins}$ & $9.82 \mathrm{Ins}$ & $4.302 * *$ & $4.025 * *$ \\
\hline Stomatal conductance & 0.246 & $0.157 \mathrm{~ns}$ & $0.186 n s$ & $0.037 * *$ & $0.039 * *$ \\
\hline Transpiration & 9.668 & 7.I40ns & $7.846 \mathrm{~ns}$ & $2.175 * *$ & 2. $124^{* * *}$ \\
\hline Leaf temperature & 33.546 & $34.947 \mathrm{~ns}$ & $34.434 \mathrm{~ns}$ & 36. $145^{* *}$ & $37.206 * *$ \\
\hline
\end{tabular}


The $g_{s}$ varied substantially from the $129.6 \mathrm{gha}^{-1}$ dose of glyphosate (Table 2), both 7 and 21 days after the application, however, with a more accentuated difference between two higher doses and the other doses on the second evaluation. Among the analyzed physiological variables, the $g_{s}$ response was the most expressive one due to the intoxication, reaching a reduction of almost $85 \%$ on the $172.8 \mathrm{gha}^{-1}$ dose on the evaluation after $2 \mathrm{I}$ days (Figure $4 \mathrm{~B}$ ).

When working with common beat, Geiger et al. (1986) observed a considerable decrease on $g_{s}$ approximately four hours after the application of 17 mmolplant ${ }^{-1}$ of glyphosate with and without surfactant. Machado et al. (20l0) reported an accentuated reduction on $g_{s}$ of eucalyptus 21 days after the application of up to $172.8 \mathrm{~g} \mathrm{ha}^{-1}$ of glyphosate.

It is known that the stomatal opening is promoted by the blue light through a specific stimulation and through the activation of the photosynthesis process on the chloroplasts or guard cells (TAIZ; ZEIGER, 2002). Therefore, if glyphosate has a negative effect on the photosynthesis, then, the opening and $g_{s}$ are partially reduced.

As a consequence of the reduction on $g_{s}$, there was a decrease on $E$ for paricá as the glyphosate doses increased. On both evaluations, the 129.6 and $172.8 \mathrm{~g} \mathrm{ha} \mathrm{ha}^{-1}$ doses differed from the control (Table 2), with a more expressive variation 21 days after the application (Figure 4C). As a response to the lower transpiration rate, an increase was observed on the $T_{f}$ (Figure 4D) with a significant variation, in comparison to the control, at the dose of $172.8 \mathrm{~g}^{\prime} \mathrm{ha}^{-1}$ at 7 days, and from the $129.6 \mathrm{~g}^{\mathrm{h}} \mathrm{ha}^{-1}$ at 2 I days after the application (Table 2).

The rise on the $T_{f}$ leads to an increase of the photorespiration and, concomitantly, to a decrease of the rubisco activity (ribulose- I,5-bisphosphate carboxylase/ oxygenase) and of the quantic yield of the photosynthesis on $\mathrm{C}_{3}$ plants, which becomes lower than on $\mathrm{C}_{4}$ plants from approximately $30^{\circ} \mathrm{C}$ on (TAIZ; ZEIGER, 2002). The increase on the photorespiration rate results on a linear decrease of the photosynthesis, that is, a lower production of photoassimilates.

\section{CONCLUSIONS}

Morphological and physiological changes occur on paricá when it is intoxicated by glyphosate. Paricá is susceptible to glyphosate with intoxication symptoms from a dose of $172.8 \mathrm{~g}^{-h^{-1}}$ of active ingredient on acid equivalent. There are no relevant damages on the stem and root of intoxicated plants, however, severe leaf loss occurs. Increasing doses of glyphosate reduce the photosynthesis, stomatal conductance and transpiration. The leaf temperature rises as the glyphosate dose increases.
The application of $196.27 \mathrm{~g} \mathrm{ha}^{-1}$ of active ingredient on acid equivalent causes $50 \%$ of intoxication on paricá.

\section{REFERENCES}

BAUR, J. R. Effect of glyphosate on auxin transport in corn and cotton tissues. Plant Physiology, v. 63, p. 882-886, 1979.

CARVALHO, C. J. R. de. Respostas de plantas de Schizolobium amazonicum [S. parahyba var. amazonicum] e Schizolobium parahyba [Schizolobium parahybum] à deficiência hídrica. Revista Árvore, v.29, n.6, p.907-9|4, 2005.

CARVALHO, F. P. de; FRANÇA, A. C.; LEMOS, V. T.; FERREIRA, E. A.; SANTOS, J. B. dos; SILVA, A. A. da. Photosynthetic activity of coffee after application of glyphosate subdoses. Acta Scientiarum. Agronomy, v. 35, n. I, p. 109-I I 5, 2013.

CARVALHO, P. E. R. Paricá - Schizolobium amazonicum. Colombo: Embrapa Florestas, 2007. 8 p. (Circular Técnica, 142).

CATANEO, A. C.; DÉSTRO, G. F. G.; FERREIRA, L. C.; CHAMMA, K. L.; SOUSA, D. C. F. Atividade de glutationa S-transferase na degradação do herbicida glyphosate em plantas de milho (Zea mays). Planta Daninha, v. 2I, n. 2, p. 307-312, 2003.

COSTA, A. C. P. R. da; COSTA, N. V. da; PEREIRA, M. R. R.; MARTINS, D. Efeito da deriva simulada de glyphosate em diferentes partes da planta de Eucalyptus grandis. Semina: Ciências Agrárias, v. 33, n. 5, p. 1663-1672, 2012.

COSTA, N. V.; ERASMO, E. A. L.; QUEIROZ, P. A.; DORNELAS, D. F; DORNELAS, B. F. Efeito da deriva simulada de glyphosate no crescimento inicial de plantas de pinhãomanso. Planta Daninha, v. 27, p. I I05-I I I0, 2009.

FUCHS, M. A.; GEIGER, D. R.; REYNOLDS, Tracey L.; BOURQUEB, J. E. Mechanisms of glyphosate toxicity in velvetleaf (Abutilon theophrasti medikus). Pesticide Biochemistry and Physiology, v. 74, p. 27-39, 2002.

FRANS, R. E. Measuring plant response. In: WILKINSON, R. E. (Ed.). Research methods in weed science. Melbourne: Southern Weed Science Society, 1972. p. 28-4I.

GEIGER, D. R.; KAPITAN, S. W.; TUCCI, M. A. Glyphosate Inhibits Photosynthesis and Allocation of Carbon to Starch in Sugar Beet Leaves. Plant Physiology, v. 82, p. 468-472, 1986.

GRAVENA, R. Respostas bioquímicas e fisiológicas de plantas de citros atingidas pelo glyphosate. 2006. I44f. Tese (Doutorado em Agronomia) - Escola Superior de Agricultura Luiz de Queiroz, Piracicaba, 2006.

HETHERINGTON, P. R.; REYNOLDS, T. L.; MARSHALL, G.; KIRKWOOD, R. C. The absorption, translocation and distribution of the herbicide glyphosate in maize expressing the CP-4 transgene. Journal of Experimental Botany, v. 50, n. 339, p. I567-I576, 1999. 
IBÁ. Relatório Ibá 20I5. 20I5. Disponível em:<http://iba.org/ images/shared/iba_20I5.pdf> Acesso em: 22 de dez. de 2015.

IBGE. Produção da extração vegetal e da silvicultura. 2014. Disponível em: <http://www.sidra.ibge.gov.br/bda/ pesquisas/pevs/default.asp > Acesso em: 22 de dez. de 2015.

LEE, T. T.; DUMAS, T. Effect of glyphosate on ethylene production in tobacco callus. Plant Physiology, v. 72, p. 855-857, 1983.

LEE, T. T.; DUMAS, T. Effect of glyphosate on indole-3-acetic acid metabolism in tolerant and susceptible plats. Journal of Plant Growth Regulation, v. 4, p. 29-39, 1985.

LOPES, M. J. dos S.; DIAS-FILHO, M. B.; MENEZES NETO, M. A.; SANTOS, J. U. M. dos; CRUZ, E. D.; DIAS, H. do S. da S. Morphological and physiological responses to shade in seedlings of Parkia gigantocarpa Ducke and Schizolobium parahyba var. amazonicum (Huber ex Ducke) Barneby (Leguminosae). Scientia Forestalis, v. 43, n. 107, p. 573-580, 2015.

MACHADO, A. F. L.; FERREIRA, L. R.; SANTOS, L. D. T.; FERREIRA, F. A.; VIANA, R. G.; MACHADO, M. S.; FREITAS, F. C. L. Eficiência fotossintética e uso da água em plantas de eucalipto pulverizadas com glyphosate. Planta Daninha, v. 28, n. 2, p. 319-327, 2010.

MAGALHÃES, P. C.; SILVA, J. B.; DURÃES, F. O. M.; KARAM, D.; RIBEIRO, L. S. Efeito de doses reduzidas de glyphosate e paraquat simulando deriva na cultura do milho. Planta Daninha, v.19, n.2, p.247-253, 200 la.

MAGALHÃES, P. C.; SILVA, J. B.; DURÃES, F. O. M.; KARAM, D.; RIBEIRO, L. S. Efeito de doses reduzidas de glyphosate e paraquat simulando deriva na cultura do sorgo. Planta Daninha, v.19, n.2, p.255-262, $200 \mathrm{lb}$.

MAPA/MDA.Plano Setorial de Mitigação e de Adaptação às Mudanças Climáticas para a Consolidação de uma Economia de Baixa Emissão de Carbono na Agricultura. Brasília, 201 I, 107p.

MARQUES, L. C. T.; YARED, J. A. G.; SIVIERO, M. A. A evolução do conhecimento sobre o paricá para reflorestamento no Estado do Pará. Belém: Embrapa Amazônia Oriental, 2006, 5 p. (Comunicado Técnico 158).

MONQUEIRO, P. A.; CHRISTOFFOLETI, P. J.; OSUNA, M. D.; DE PRADO, R. A. Absorção, translocação e metabolismo do glyphosate por plantas tolerantes e susceptíveis a estes herbicidas. Planta Daninha, v. 22, n. 3, p. I23-132, 2004.

Lewis, G. P. Schizolobium in Lista de Espécies da Flora do Brasil. Jardim Botânico do Rio de Janeiro. Disponível em: <http://floradobrasil.jbrj.gov.br/jabot/floradobrasil/ FB23 |44>. Acesso em: 06 de maio 2016.

ROSA, L. dos S. Características botânicas, anatômicas e tecnológicas do paricá (Schizolobium amazonicum Huberr ex Ducke). Revista de Ciências Agrárias, v. 46, p. 63-79, 2006 a.

ROSA, L. S. Ecologia e silvicultura do paricá (Schizolobium amazonicum Huber ex Ducke) na Amazônia brasileira. Revista de Ciências Agrárias, v. 45, p. I35- I 74, 2006 b.
SALGADO, T. P.; ALVES, P. L. C. A.; KUVA, M. A.; TAKAHASHI, E. N.; DIAS, T. C. S.; LEMES, L. N. Sintomas da intoxicação inicial de Eucalyptus proporcionados por subdoses de glyphosate aplicadas no caule ou nas folhas. Planta Daninha, v. 29, n. 4, p. 913-922, 201 I.

SANTOS JUNIOR, A.; TUFFI SANTOS, L. D.; FERREIRA, F. A.; FERREIRA, L. R.; FELIX, R. C.; AMARAL, G. C.; CRUZ, L. R.; Glyphosate drift in eucalyptus plants. Planta Daninha, v. 33, n. 3, p. 615-62I, 2015 .

SCHALLER, G. E.; KIEBER, J. J. Ethylene. The Arabidopsis Book, v. I, p.I-I7, 2002.

SERVAITES, J. C.; TUCCI, M. A.; GEIGER, D. R. Glyphosate Effects on Carbon Assimilation, Ribulose Bisphosphate Carboxylase Activity, and Metabolite Levels in Sugar Beet Leaves. Plant Physiology, v. 85, p. 370-374, 1987.

SILVA, A. A. da; FERREIRA, F. A.; FERREIRA, L. R.; SANTOS, J. $B$. dos. Métodos de controle de plantas daninhas. In: SILVA, A. A. da; SILVA, J. F. da (Ed.). Tópicos em manejo de plantas daninhas. Viçosa: Ed. UFV, 2007a. p 4I-57.

SILVA, A. A. da; VARGAS, L.; FERREIRA, A. E. Herbicidas: resistência de plantas. In: SILVA, A. A. da; SILVA, J. F. da (Ed.). Tópicos em manejo de plantas daninhas. Viçosa: Ed. UFV, 2007b. p 240-28I.

SILVA, N. R. da; COSTA, F. R. da; CARVALHO, L. B. de. Acúmulo diferencial de massa seca em eucalipto e pinus expostos a glyphosate. Revista de Ciências Agroveterinárias, v. I4, n.2, p. I86-190, 2015.

TAIZ, L.; ZEIGER, E. Plant physiology. 3.ed. Sunderland: Sinauer Associates, 2002. 690 p.

TUFFI SANTOS, L. D.; FERREIRA, F. A.; FERREIRA, L. R.; DUARTE, W. M.; TIBURCIO, R. A. S.; SANTOS, M. V. Intoxicação de espécies de eucalipto submetidas à deriva do glyphosate. Planta Daninha, v. 24, n. 2, p. 359-364, 2006.

TUFFI SANTOS, L. D; MACHADO, A. F. L.; VIANA, R. G.; FERREIRA, L. R.; FERREIRA, F. A.; SOUZA, G. V. R. Crescimento do eucalipto sob efeito da deriva de glyphosate. Planta Daninha, v. 25, n. I, p. I33-137, 2007a.

TUFFI SANTOS, L. D.; MEIRA, R. M. S. A.; FERREIRA, F. A.; SANT'ANNA-SANTOS, B. F.; FERREIRA, L. R. Morphological responses of different eucalypt clones submitted to glyphosate drift. Environmental and Experimental Botany, v. 59, p. II-20, 2007b.

TUFFI SANTOS, L. D.; SANT'ANNA-SANTOS, B. F; MEIRA, R. M. S. A.; FERREIRA, F. A.; TIBURCIO, R. A. S.; MACHADO, A. F. L. Leaf anatomy and morphometry in three eucalypt clones treated with glyphosate. Brazilian Journal of Biology, v. 69, n. I, p. I29-136, 2009.

WAGNER JÚNIOR, A.; TUFFI SANTOS, L. D.; SANTOS, C. E. M.; SILVA, J. O. C.; PIMENTEL, L. D.; BRUCKNER, C. H.; FERREIRA, F. A. Deriva simulada de formulações comerciais de glyphosate sobre maracujazeiro amarelo. Planta Daninha, v. 26, n. 3, p. 677-683, 2008. 
YAMADA, T.; CASTRO, P. R. de C. e. Efeitos do glifosato nas plantas: implicações fisiológicas e agronômicas. Informações Agronômicas, n. II9, p. I-32, 2007.
YAMASHITA, O. M.; VIEIRA, R. G.; SANTI, A.; RONDON NETO, R. M.; ALBERGUINI, S. E. Resposta de varjão (Parkia multijuga) a subdoses de glyphosate. Planta Daninha, v. 24, n. 3, p. 527-53।, 2006. 